\title{
Academics agonize about weapons labs
}

\section{Livermore and Los Alamos up for grabs}

\section{San Francisco}

In what promises to be another stormy round in a long-running debate, the Board of Regents of the University of California is meeting next week to discuss how it should increase its control of research programmes at the two weapons laboratories which the university runs for the Department of Energy (DoE).

The present five-year management contract for the two laboratories - at Livermore and Los Alamos - runs out in 1982 , and preliminary moves to negotiate a new contract with the department have restimulated discussion of the implications of the university's responsibility for the research that underpins a major part of the world's nuclear arsenal.

Last year, the Board of Regents, which is responsible to the state for the university's affairs, rejected a proposal from ex-officio member Governor Jerry Brown to remove all military research from the Lawrence Livermore Laboratory, and in September voted to open discussions with DoE for a new contract. The focus of debate has therefore shifted from whether the Livermore Laboratory should be carrying out weapons research at all to how the university should exercise its management responsibilities over this research. In particular, opinions differ about the extent to which the Board of Regents - and possibly outside advisers - should be involved in determining research priorities for the laboratory.

Under the present arrangement the university accepts responsibility for the quality of the research but leaves priorities almost entirely to DoE, a situation which many scientists and administrators at the laboratory are reluctant to see changed. "If a car is running well, you don't tamper with the engine", one Livermore official said last week.

Some members of the university faculty are, however, concerned about the lack of control over military research programmes. The autonomy enjoyed by the laboratories under the protection of the university was described in a report as "so delightful as to border on the licentious". More recently, a group of laboratory staff at Livermore, known as the Society of Professional Scientists and Engineers, has suggested that there should be greater outside monitoring of research.

At the same time, the university is keen to keep a contract which brings in $\$ 4$ million a year in management fees, and it points out that several recent reports, including one prepared by the department's Energy Research Advisory Board, have concluded that it is in the best interests of both sides that the basic links with the university be maintained.

At its meeting last month, the Board of Regents received two proposals for modifying the relationship. Professor William Fretter, the university's vicepresident, suggested that the regents appoint a new oversight committee to "provide increased accountability to the general public", and that this committee establish three evaluation committees, one of which would be responsible for establishing research priorities.

The second proposal came from Governor Brown and is based on the report of a committee which the university itself set up in 1978. Like Professor Fretter, the governor also proposes a new oversight committee, but this time assisted by an independent advisory board.

The two proposals agree on many points, but also have significant differences. For example, while the evaluation committees proposed by Professor Fretter would essentially be subcommittees of the oversight committee, Governor Brown's advisory committee would have much greater autonomy, being empowered to request that the oversight committee help it evaluate particular programmes or problems.

The composition of the proposed committees would also differ significantly. The evaluation committees proposed by Professor Fretter would chiefly consist of experts from within and outside the university. In contrast, Governor Brown

contemplates an advisory board of scientists, faculty members, students, health experts, theologians and others.

The president's office is now deciding whether the two proposals can be combined. Otherwise, the choice between the two approaches will have to be made by the regents.

Whatever the result, increased control at least of research not related to weapons, which forms about half of the work of both laboratories - seems inevitable. The university's president, Dr David Saxon, has already proposed setting up a panel of scientists to recommend research priorities in energy research and other unclassified areas at the two laboratories.

More controversial is the extent to which an oversight committee should be involved in policy decisions about weapons research, which is shortly expected to include work on the MX missile system. Here both university and laboratory of ficials argue that all such policy decisions must be made at the national level in Washington, and that the laboratories should only carry out Washington's requests.

Critics point out, however, that in the past laboratory officials have been far from neutral in policy debates over weapons research and related areas of arms control. For example, pressures from the two weapons laboratories were significant in reducing the scope of the Comprehensive Test-Ban Treaty now being negotiated in Geneva, while other laboratory officials have been active in the debate over whether to ratify the Strategic Arms Limitation Treaty (Salt II).

David Dickson

\section{Short commons for Spanish research}

A ten-month freeze on research grants for scientists in Spanish universities and the Spanish National Research Council ended on 20 October with the distribution of 3,600 million pesetas ( $£ 22$ million) to groups in the universities and the research council. The average of $£ 24,000$ per group must officially last three years - although the period may in practice be longer. Grants were last awarded in 1976.

The distribution has come in for some severe criticism, particularly from members of the group of 200 leading scientists who, just before the grants were announced, had sent a manifesto to the Minister of Universities and Research describing his policies as "derelict" (Nature 23 October, p.674). The group now says that the meagre distribution is no surprise. Spain historically has spent only 0.3 per cent of its gross national product (GNP) on research and development compared with about 2 per cent in other Western countries. Passions have, however, been stirred by the way in which this distribution has been made.

One member of the group says that a key advisory body has been ignored, and that grants have been awarded by subject panels which were not best qualified to make judgements. The result has been a largely random distribution of money, he claims. Some of these discontents were aired at the meeting on European Economic Community (EEC) science policy held two weeks ago in Strasbourg.

The advisory body, the Gabinete de Estudios, was set up four years ago by the now deputy director-general of the United Nations Educational, Scientific and Cultural Organization, Professor Federico Mayor, to provide baseline studies of science in Spain and to advise the Comision Asesora de Investigación Científica y Tecnica (CACT), which distributed last month's grants. But the Gabinete's recommendations of referees for the grant applications were rejected, said the 